Article

\title{
Modelling Tourists' Acceptance of Hotel Experience-Enhancement Smart Technologies
}

\author{
Donglin Han ${ }^{1}\left(\mathbb{D}\right.$, Huiying (Cynthia) Hou ${ }^{2, *}$, Hao Wu ${ }^{3}\left(\mathbb{D}\right.$ and Joseph H. K. Lai ${ }^{4}(\mathbb{D}$ \\ 1 School of International Studies, Renmin University of China, Beijing 100872, China; donglin2006@gmail.com \\ 2 Department of Management in the Built Environment, Delft University of Technology, \\ 2628 CD Delft, The Netherlands \\ 3 Faculty of Architecture Building and Planning, The University of Melbourne, Melbourne, VIC 3010, Australia; \\ haow@unimelb.edu.au \\ 4 Department of Building Services Engineering, Faculty of Construction and Environment, The Hong Kong \\ Polytechnic University, Hong Kong; bejlai@polyu.edu.hk \\ * Correspondence: h.hou@tudelft.nl
}

Citation: Han, D.; Hou, H.; Wu, H.; Lai, J.H.K. Modelling Tourists' Acceptance of Hotel ExperienceEnhancement Smart Technologies. Sustainability 2021, 13, 4462.

https://doi.org/10.3390/su13084462

Academic Editor: Sara Shirowzhan

Received: 16 March 2021

Accepted: 14 April 2021

Published: 16 April 2021

Publisher's Note: MDPI stays neutral with regard to jurisdictional claims in published maps and institutional affiliations.

Copyright: (c) 2021 by the authors. Licensee MDPI, Basel, Switzerland. This article is an open access article distributed under the terms and conditions of the Creative Commons Attribution (CC BY) license (https:/ / creativecommons.org/licenses/by/ $4.0 /)$.

\begin{abstract}
Whereas the use of specific smart technologies in various sectors of the tourism industry has been under greater scrutiny in recent years, research that investigates tourists' acceptance of smart technologies applied as a whole to hotels is largely underexplored. To address this shortfall, a study with a focus on tourists' acceptance of experience-enhancement smart technologies has been conducted. A technology acceptance model based conceptual framework was developed, followed by a series of interviews with the managerial staff of ten hotels in Hong Kong that adopt experienceenhancement smart technologies. Based on the interview findings, a questionnaire was designed for use in a survey in which data were collected face-to-face from 312 tourists. Structural equation modelling was utilised to reveal the interrelationships between nine technology acceptance parameters. This study contributes knowledge to both real-world practice and research in tourism management.
\end{abstract}

Keywords: hotel; experience-enhancement smart technology; structural equation modelling; technology acceptance model; tourist

\section{Introduction}

Information technologies have transformed the built form, infrastructure, ecosystem services and human services. Smart technologies, referred to as both hardware and software technology instruments that support inter-connectivity, have been increasingly used to provide convenience to tourists in searching for information, increase the operation efficiency of the hospitality sector, and promote hotels and tourist destinations. The hospitality industry, with its core value reliant on services delivery and quality, has been significantly influenced by smart technologies.

Developed from a number of enabling technologies-including video analytic, robotics, internet of things (IoT), data analytics and cloud technology, artificial intelligence (AI) and machine learning [1] - smart technologies in the hospitality industry generally fall into two categories: operation related (e.g., property management system, revenue management technology) and experience-enhancement related (e.g., facial recognition technology, smart room electronic control, virtual reality experience) [2]. Recently, such smart technologies have been extended to cover the applications on enhancing tourists' travelling experience and personal sensations [3].

In fact, the emergence of hotel smart technologies applications that enhance guests' experience has triggered discussions on their usefulness, user-friendliness and security as well as users' intention to use the technologies. With these issues are closely related to user behaviours, studies on guests' acceptance of specific smart technologies in the hotel sector, such as hotel reservation website [4], self-service technologies $[5,6]$ and hotel access 
control system [7], have grown. Yet, studies on hotel guests' acceptance of experienceenhancement smart technologies remain to be seen. Aimed at contributing knowledge to this niche area and since understanding users' intention to use smart technologies is crucial to the long-term development of hotels' business, a study, as reported below, was initiated. The study gave special emphasis on two research questions, namely: (1) what factors affect tourists' acceptance of experience-enhancement smart technologies, and (2) how do these factors affect the tourists' intention to use experience-enhancement smart technologies.

This paper is structured as follows: Section 2 is a literature review on the definitions of smart technologies, their applicability to the hospitality industry, and recent studies on smart technologies in hotels. Section 3 clarifies the scope of experience-enhancement smart technologies and identifies the research gap that this study aims to fill. Section 4 develops a theoretical framework for the study, including the representations of the conceptual constructs and the hypotheses that the following sections test. Section 5 reports the research methodology and the data collected. Section 6 explains the data analysis processes and presents the findings. After highlighting the theoretical and practical implications in Section 7 , the conclusions are drawn in Section 8.

\section{Literature Review}

\subsection{Smart Technologies: Definitions, and Functions for the Hospitality Industry}

Smart technologies refer to a combination of functions provided by both hardware and software components to establish seamless connection within the social space, taking the form of smart devices and smart systems [8,9]. Smart technologies can also be understood on two dimensions: enabling technologies and applied technologies. Enabling technologies, including video analytics, robotics, IoT, data analytics and cloud technologies, AI and machine learning, form the foundation of applied technologies. One type of applied technology is facial recognition, which was developed based on video analytics. Robot concierges, robotic vacuums, in-room service robots, etc. are developed based on robotics technology and IoT. Luggage tags in storerooms, in-room lighting sensors, automatic minibar items checking, etc. are technological manifestations of IoT. A smart hotel room consists of IoT-connected devices used to provide a seamless guest experience [7]. The emergence of IoT has extended the social space from its physical dimension to a virtual dimension [10].

In a general sense, Worden et al. [11] described smart technologies by emphasising the versatility of technologies that are adaptable to specific circumstances. Leonidis et al. [12] described "smartness" in the hospitality context as an efficient business ecosystem empowered by technologies. Zoughbi and Al-Nasrawi [13] described smart technologies in three "smart aspects": (1) automatic functions that provide customer driven service, (2) information collection, and (3) automatic learning that improves operating performance. Li et al. [14] defined smart technologies as the mechanism to facilitate positive consumer experience as well as collect customer information and use it to improve service performance.

As smart technologies are being integrated in a variety of social and business spheres, the meaning of smart technologies varies with the context in which it is applied. Widely applied to people's livelihood, environmental protection, public security, city services and other dimensions [15], smart technologies have been profoundly embraced in the hospitality industry, especially the tourism and hotel sectors [2]. The embeddedness of "smartness" in the hospitality industry originates from the adoption of new technologies to enable the operation systems to function in an interoperable and interconnected manner [12,16].

Smart technologies not only improve management capacity and operational efficiency of specific hospitality sectors, but they also enhance service quality and user satisfaction $[7,17-23]$. Operation costs are significantly reduced by integrating smart features in operation processes $[19,24,25]$. With the proliferation of information and communication technology (ICT) and its wide use in the marketing domain, "smartness" or IoT is embedded in creating consumer experience and disseminating marketing information [22,26-28]. 


\subsection{Studies on Smart Technologies in the Hotel Sector}

Research on smart technologies in the hotel sector includes behavioural studies. This group of studies enhances our understanding of business stakeholders' attitudes towards smart hotel technologies [29], hotel owners' perspectives towards adopting smart technology [30], employees' intention to adopt information technologies [31-34], and hotel guests' or travellers' attitudes, perceptions towards and experiences with smart hotel technologies [5,7,35-37]. In particular, Murphy and Rottet [35] proposed and examined factors that affect hotel guests' willingness to adopt biometric devices. Kim et al. [5] investigated the concept of customer readiness and its effects on likelihood of using self-service technologies in a hospitality setting. In this same area, Shin and Perdue [38] conducted bibliometric analysis on the adoption of self-service technology in the hospitality industry.

Various models have been introduced or used in research relevant to the current study. Lam et al. [31] investigated the relationship between attitude, self-efficacy, and subjective norm and behavioural intention towards hotel employees' perceptions of information technology adoption. Based on the data collected from hotels in Hangzhou, China, they show that attitude, self-efficacy and subjective norms are positively related to behavioural intention; perceived IT beliefs had influence on the intention through attitude formation and task-technology fit appears to interact with perceived IT beliefs towards attitude formation. Sarmah et al. [36] developed an extended technology-based service adoption model to investigate hotel guests' innovativeness, willingness to co-create, demand for interaction and involvement on their intention to collectively develop new services using smartphone apps. Their findings reveal that both guests' innovativeness and need for interaction with service staff significantly affect their involvement. A guest's willingness to co-create acts as a partial mediator between his/her innovativeness and intention to adopt co-creatively developed new services. Focusing on a hotel access control system, Lim et al. [7] applied the technology acceptance model to examine hotel guests' acceptance of the system for seamless hotel check-in and room access. The results of their study show that the ease of using and usefulness of the system significantly facilitated seamless experiences in hotel check-in and room access, which in turn, significantly shaped attitudes towards using the system. By collecting hotel customers' opinions at a smart hotel, Wu and Cheng [37] used a conceptual model to synthsise the dimensions of technology attachment, dimensions of experiential relationship quality, experiential risk and experiential sharing intention. In their study, technology identity, technology affection and technology social bonding were proved to play important roles in increasing customers' confidence in the smart technology provided by the smart hotel; technology dependence, technology identity and technology affection plays critical roles in influencing perceptions of experiential satisfaction; further, experiential satisfaction has a positive influence on experiential trust, and experiential trust and experiential satisfaction positively influence experiential sharing intentions. Sun et al. [34] investigated the impacts of individual-level cultural values (e.g., collectivism, power distance, long-term orientation, uncertainty avoidance, and masculinity) on the technology acceptance model (e.g., perceived usefulness, perceived ease of use) with the data collected from employees in the hotel industry in the U.S. context. Ten hypotheses were developed to test he relationships between the five individual-level cultural values and the TAM model. The results show that eight hypotheses were supported and the proposed seven-factor model is valid and reliable. In examining hospitality platforms that are supported by smart technologies, Buhalis and Leung [2] propose a 'smart hospitality ecosystem' which can add value to its stakeholders.

The above studies show that smart technologies applied in hotels are important elements affecting tourists' experience, hotel operation and the landscape of hotel business in the long term. However, so far, no studies have comprehensively investigated the major smart technologies that are involved in tourists' experience enhancement, which represents the core value of the hotel sector-providing services that create memorable experiences for their guests. As such, it is necessary to study experience-enhancement smart technologies applied in the hotel sector, including the perception of hotel users of such technologies. 


\section{Experience-Enhancement (EE) Smart Technologies}

Users of smart technologies in the hotel sector fall into three categories: operators, tourists and linked external parties [2]. This study focuses on the smart technologies that are accessible to tourists who stay at hotels as patrons, viz. "experience-enhancement (EE) smart technologies". This notion of technology is directly associated with tourists' hotel stay experience and their satisfaction in hotel services such as smart check-in/out (e.g., using smartphone apps or check-in kiosk, IoT facilitated electronic bill for check-out), smart concierge (e.g., beacons enabled with location identification and digital guidance inside hotel areas, restaurant/entertainment activity recommendations or bookings through smartphone apps, virtual reality experience), smart in-room services (e.g., e-key within the guests' personal devices, facial recognition or beacons, IoT supported mobile apps for in-room electronic control, voice-enabled virtual assistance, room services delivered by autonomous robot, e-housekeeping apps), etc. These smart technologies are embedded in the "guest touchpoints" which are referred to as points of contact for human-interactive service to enhance guests' experience, such as search, booking, greetings and check-in, stay, check-out. For example, at the greeting and check-in touchpoint, after the tourists enter the hotel lobby, smart cameras with facial-recognition capabilities recognise them from the passport photo submitted during mobile check-in prior to arrival. Some hotels develop mobile app with which tourists can conduct fast check-in on their own and a mobile key is then activated for the tourists to enter their room.

Aside from enhancing tourists' experience, another important business strategy behind the development of EE smart technologies is to collect service users' personal behavioural data in order to further develop and improve personalised services. Personalisation is an important approach to delivering services that meet customer expectations, that is, to provide customised services to match customers' needs and preferences [39]. Collecting users' behavioural information to form a comprehensive database for the analysis of customer choices is key to meeting customer expectations [40]. Customers' inherent preferences revealed in the service consumption process are essential for the service providers to achieve personalisation in their service design and planning [41]. In the near future, a variety of EE smart technologies will be provided to improve service delivery as well as facilitate the formation of "internal big data" to enhance personalised services [2]. Therefore, understanding the acceptance of EE smart technologies is pivotal to the strategic development of personalised services in the hotel sector.

\section{Conceptual Framework Development}

Many studies have adopted technology acceptance (TAM) extended models to explain tourists' acceptance of various hospitality and tourism technologies. For example, Lai [42] summarised the tourists' acceptance of smart technologies studies published from 2005 to 2012 and analysed the TAM extended models adopted in studies on tourism websites, online booking systems, travel e-shopping, hotel reservation websites, internet adoption, airlines, online travel communities, property management system in hotels and Facebook. Since 2012, more studies on smart technologies acceptance in hospitality settings from the tourists' perspective have been conducted, including radio-frequency identification (RFID) technology acceptance in the hospitality industry [43], smart technologies in airline ticket purchase [44,45], self-service kiosk at hotels [6], self-service technologies in hospitality settings [5], hotel tablet apps [46], social media networks [47] and hotel access control system [7].

In a hospitality setting, employees are often under pressure to take up new technologies for achieving organisational or career goals. But tourists, who are customers of the hospitality sector, are free to choose whether or not to use those technologies according to their own wishes. This implies that decisions of tourists on using smart technologies is attributed to their beliefs. Thus, TAM is suitable for investigating the smart technologies adoption behaviour from the tourists' perspective. 


\subsection{Technology Acceptance Model (TAM) and Its Three Approaches for Extension}

TAM was initially developed to test employee intentions to adopt new technologies for efficiency services [48]. It has proven powerful to represent the antecedents of the intention to adopt new technologies [49,50]. TAM adapts its framework from the theory of reasoned action (TRA) for user acceptance of information systems. It assumes one's actual use of new technology is directly or indirectly influenced by one's behavioural intention, attitude, perceived usefulness of the technology and perceived use of the technology. One's behaviour is affected by one's behavioural intention and shaped by one's attitude [51]. Studies on technology acceptance commonly focus on the relationships among beliefs (perceived usefulness, perceived ease of use, etc.), attitude, behavioral intention and action.

Perceived usefulness (PU), perceived ease of use (PEU), attitude towards use (ATU) and intention to use (ITU) technology are the four theoretical components of TAM. PU refers to the technology users' belief that new technology improves the performance of a certain task [4] and PEU describes the extent of convenience and effortlessness of using new technology $[52,53]$. ATU is the emotion and judgement towards using technology; favourable attitude towards new technology results in strong ITU [54,55].

Although TAM has been criticised for its oversaturation, it is still considered as one of the most widely accepted models in studying consumer behaviour in the hospitality industry [33]. Over the past three decades, TAM has been used as a theoretical foundation to examine new technology acceptance in many social disciplines, with the support of empirical data. According to Wixom and Todd [56], there are three main approaches to developing extended TAM models: the first is by introducing variables from related models-subjective norms and perceived behavioural control in the theory of planned behaviour (TPB) are commonly integrated to form an extended TAM model for explaining their influence on behavioural intention; the second is by incorporating new belief factors to test their predictive powers on attitude towards new technologies; the third is by introducing external variables as antecedents to TAM on attitude through PU or PEU.

Assuming user behaviour may vary in different technology use contexts, additional constructs were proposed to form an extended TAM model and test their relationships in the context of hotels. Figure 1 illustrates the conceptual framework of this model (green dotted box); it incorporates the applicable variables of the three approaches summarised by Wixom and Todd [56]: TPB, behavioural belief factors and external variables affecting TAM, as in the blue, brown and purple dotted boxes, respectively. The next part further elaborates the hypotheses developed based on the conceptual framework.

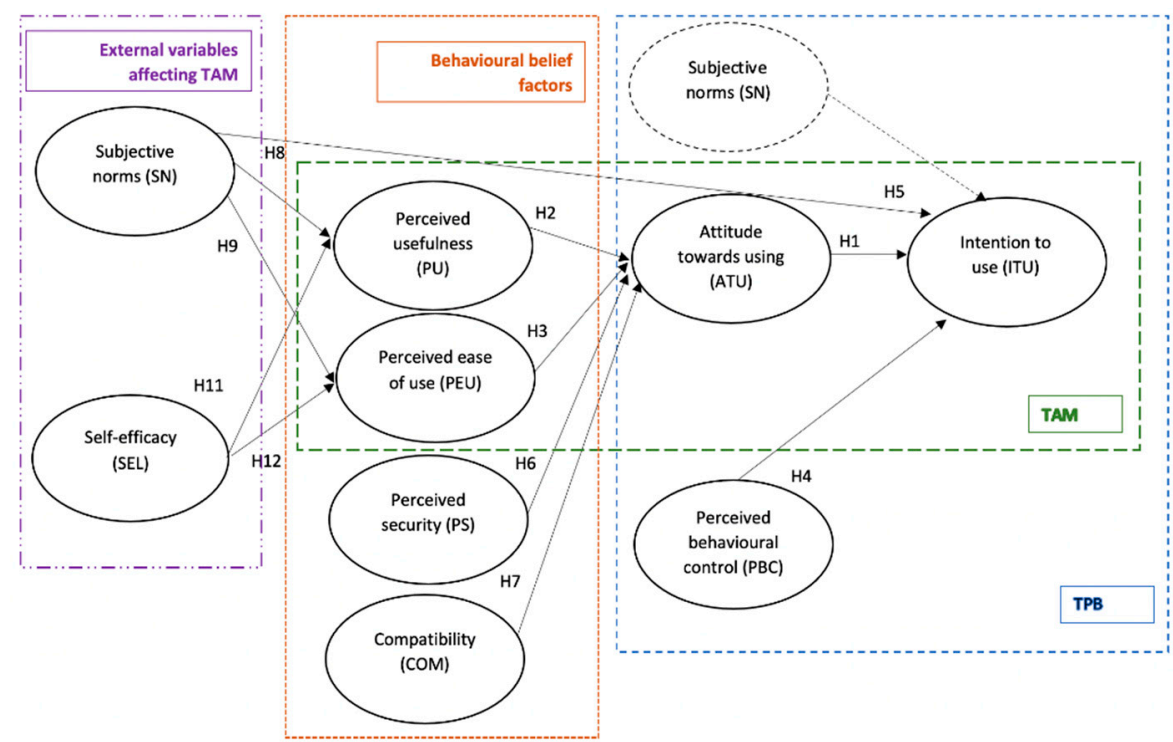

Figure 1. TAM-based conceptual framework; Source: authors. 
Whether tourists accept smart technologies in the hotel sector and so are willing to use them is of empirical value. Whether tourists have positive perceptions of or hold positive attitudes towards smart technologies is a key to predicting their intention to use. Attitude plays an influential role in tourists' intention of using smart technologies. A tourist has the option between smart technologies and traditional service. PU and PEU are the two variables that reflect the tourist's perception of outcome (effectiveness of service) and process (convenience and time-saving efficiency). According to the traditional TAM model (see green dotted box in Figure 1), it is hypothesised that PU and PEU influence ATU and that ATU is positively associated with ITU:

Hypothesis 1. Tourists' ATU smart technologies positively affects their ITU.

Hypothesis 2. Tourists' PU of smart technologies positively affects their ATU.

Hypothesis 3. Tourists' PEU of smart technologies positively affects their ATU.

\subsection{The Theory of Planned Behaviour (TPB) and Associated Factors}

Extended from the theory of reasoned action (TRA) [57], TPB offers further theoretical insight into human intentions [58], which involves perceived behaviour control (PBC), subjective norms (SN) and attitude towards using (ATU). Traditional technology acceptance research often introduces factors of TPB to model behaviour of using technology [59-62]. This study incorporates the factors of TAM (see Figure 1), PBC, SN, as well as perceived security (PS) and compatibility (COM) that influence hotel guests' intention to use smart technologies.

\subsubsection{Perceived Behavioural Control (PBC) and Subjective Norms (SN)}

In the TPB model, PBC refers to an individual's perception of the possible difficulties when demonstrating a specific behaviour [58,63]. TPB hypothesises that the more an individual is able to have control over opportunities and resources to perform a specific behaviour, the more likely the behaviour will occur [63]. In the context of hotels, tourists' possession of certain resources or opportunities motivates them to use technologies, such as owning a smartphone with internet data connectivity. Without data connectivity, tourists are unable to use smart technologies provided by hotels. It is straightforward for the tourists to decide on their level of perceived behavioural control over smart technologies.

$\mathrm{SN}$ is "a person's perception that most people who are important to him think he should or should not perform the behaviour in question" [57]. Its role is perceived differently in TAM and TRA. In TRA, SN is believed to directly influence ITU, while TAM does not include SN to influence ITU. In TPB, SN is among the three factors that directly affect ITU [64]. This variable may play a significant role when one travels with his or her family members or good friends. The three theoretical components of TPB are merged in the TAM-based model (blue dotted box in Figure 1), in which SN is proposed as a factor directly and indirectly affecting ITU (affecting TAM as an external variable-shown in the purple dotted box).

Hypothesis 4. Tourists' PBC positively affects their ITU smart technologies.

Hypothesis 5. Tourists' SN positively affects their ITU smart technologies.

\subsubsection{Perceived Security (PS) and Compatibility (COM)}

Using smart technologies usually incurs data privacy concerns. To use an app, registration usually requires one to provide his or her phone number, email, home address or credit card information. PS is considered as a key factor affecting technology acceptance, and it has been widely studied in industries concerning information security, such as online banking [65]. PS of hotel customers relates to their trust in the hotel organisation as well as the relevant information systems [66]. It is essential for hotel managers to understand whether PS is a barrier to the use of smart technologies. Tourists' data privacy concerns 
are: (1) whether their personal information will be stored properly; (2) whether their information will be manipulated for third party marketing; and (3) whether their information will be obtained by a third party without their consent, etc.

User attitude towards using smart technologies relates to how "they feel or think about an innovation" and whether the technologies meet their need in doing things [67,68]. Compatibility (COM) describes people's behaviour of using an innovation that is consistent with their "existing sociocultural values and beliefs, past and present experiences and needs of potential adopters" [69]. It has been identified as an essential factor for innovation adoption $[69,70]$ and has proved to have significant effects on attitude and/or intentions [60,71]. Tourists' attitude towards using smart technologies is considered to be associated with their perception of innovation, as most smart technologies that hotels adopt such as facial recognition check-in, service robot delivery, and virtual reality (VR) technologies for room selection preview are highly innovative. Furthermore, past experience of using smart technologies also affect customer attitude. For example, if a customer is familiar with smart technologies for daily life activities, he or she would be more willing to use similar technologies for hotel services. In this study, PS and COM are proposed to be two behavioural belief factors along with PU and PEU affecting ITU through ATU.

Hypothesis 6. Tourists' PS positively affects their ATU smart technologies.

Hypothesis 7. Tourists' COM positively affects their ATU smart technologies.

\subsection{External Variables: Subjective Norms (SN) and Self-Efficacy (SEL)}

In some contexts, the original TAM may fail to capture certain human motives of technology acceptance [61]. Davis [52] proposed that some external factors affect ITU by exerting mediating effects on PU and PEU. Aside from directly influencing ITU, subjective $\mathrm{SN}$ is also proposed in this study as an external factor influencing TAM (purple dotted box in Figure 1 refers). In the context of using hotel smart technologies, SN is regarded as influencing user attitude towards smart technologies. One's attitude of using environmental friendly-products can be heavily affected by cognitive distance (or 'importance') [72,73]. For example, a person who regards the smart-check-in app as a preferred tool is likely to influence the attitude of another (e.g., friend or family member) to use the app, thus motivating the ITU of the latter. This is generally supported in the TPB literature.

Fundamentally, smart technologies can provide convenience and enhance users' experience of their stay. SN, a social influence factor, is regarded as related to one's attitude through PU. Venkatesh and Davis [74] proposed that SN has influence on both PU and ITU in the TAM model. It is thus reasonable to propose that a person's attitude towards a hotel smart technology can change if someone important to this person considers that the technology is useful for obtaining the relevant hotel service. For example, when the hotel check-in queue is long, a family member's suggestion to use a smart check-in function can be persuasive, affecting the attitude of the other family members towards the queuing. In other words, SN influences one's attitude through PU. SN is the antecedent of PEU to influence ATU.

Hypothesis 8. Tourists' SN positively affects their PU of smart technologies.

Hypothesis 9. Tourists' SN positively affects their PEU of smart technologies.

Besides social pressure factors, one's capability to use smart device may influence one's PU and PEU of smart technologies. SEL is used to describe one's capability to use a computer in technology acceptance studies [75]. Using smartphones or other devices to receive services can be a barrier to tourists. Some smart hotel technologies are not easy to comprehend. A concomitant hypothesis is that one's capability to use smart device, represented by SEL, positively influences PU and PEU (purple dotted box in Figure 1 refers). 
Hypothesis 10. Tourists' SEL positively affects their PU of smart technologies.

Hypothesis 11. Tourists' SEL positively affects their PEU of smart technologies.

\section{Research Methodology}

Subsequent to the literature review above and conceptual model building processes, the study proceeded with two more stages: interviews and a survey. Both interviews and the survey were conducted from January to May 2019. As not all hotels are equipped with smart technologies, it is necessary to investigate whether smart technologies have been adopted by the target hotels and, if so, what sorts of technologies have been in use. For this purpose, interviews were held with the hotels' managerial staff to discuss the current application of experience-enhancement smart technologies in their hotels. The interview findings, particularly on the smart technologies adopted, formed the basis for designing a survey in the next stage.

\subsection{Interviews}

Interview invitations were issued via mass email to the 235 hotels that were listed on the Hong Kong Tourism Board PartnerNet [76]. Ten hotels, graded between 3-star and 5 -star and located in eight different districts of Hong Kong, accepted the invitation. For each of these hotels, one to two managerial staff were interviewed face-to-face to identify the EE smart technologies that they have adopted and to discuss how the technologies were applied to enhance tourists' user experience. Each interview lasted approximately $45 \mathrm{~min}$ to one hour and only involved one interviewee. A total of 13 interviews were conducted. After explaining the definition and scope of experience-enhancement smart technologies, three questions were asked: (1) Can you briefly introduce the hotel where you work and your role/position at the hotel? (2) What types of smart technologies are adopted in your hotel? (3) How are they applied in the hotel operation process to enhance tourists' user experience? Table 1 summarises the profiles of the hotels and interviewees.

Table 1. Profiles of the hotels and interviewees.

\begin{tabular}{cccccc}
\hline Hotel & Location (District Name) & Start Rating & Style & $\begin{array}{c}\text { No. of Interviewees } \\
\text { from Each Hotel }\end{array}$ & Department of the Interviewee \\
\hline Hotel A & Tsim Sha Tsui & 5 & Luxury hotel & 1 & Marketing \\
Hotel B & West Kowloon & 5 & Luxury hotel & 1 & Marketing \\
Hotel C & Hung Hom & 5 & Luxury hotel & 2 & Concierge \\
Hotel D & Admiralty & 5 & Luxury hotel & 1 & Concierge \\
Hotel E & Southern District & 5 & Luxury hotel & 1 & Finance \\
Hotel F & Kwun Tong & 4 & Boutique hotel & 1 & Marketing \\
Hotel G & Quarry Bay & 4 & Boutique hotel & 2 & IT; Customer communication \\
Hotel H & Mong Kok & 4 & Boutique hotel & 1 & IT \\
Hotel I & Sheung Wan & 4 & Boutique hotel & 2 & Customer communication; \\
Hotel J & Tsim Sha Tsui & 3 & Business hotel & 1 & General management \\
\hline
\end{tabular}

Source: Authors' data based on the interview results.

During the interviews, the hotel managerial staff indicated the smart technologies adopted in the hotels where they worked, and explained the purpose of the smart technologies, their functions and operation process. The EE smart technologies were identified through the interviews and were summarised and then categorised based on five "guest service touchpoints": search, booking, greetings, check-in, stay (in-room and other service areas) and check-out. Figure 2 illustrates the identified hotel smart technologies and the touchpoints at which they are applied in the hotels in Hong Kong. 


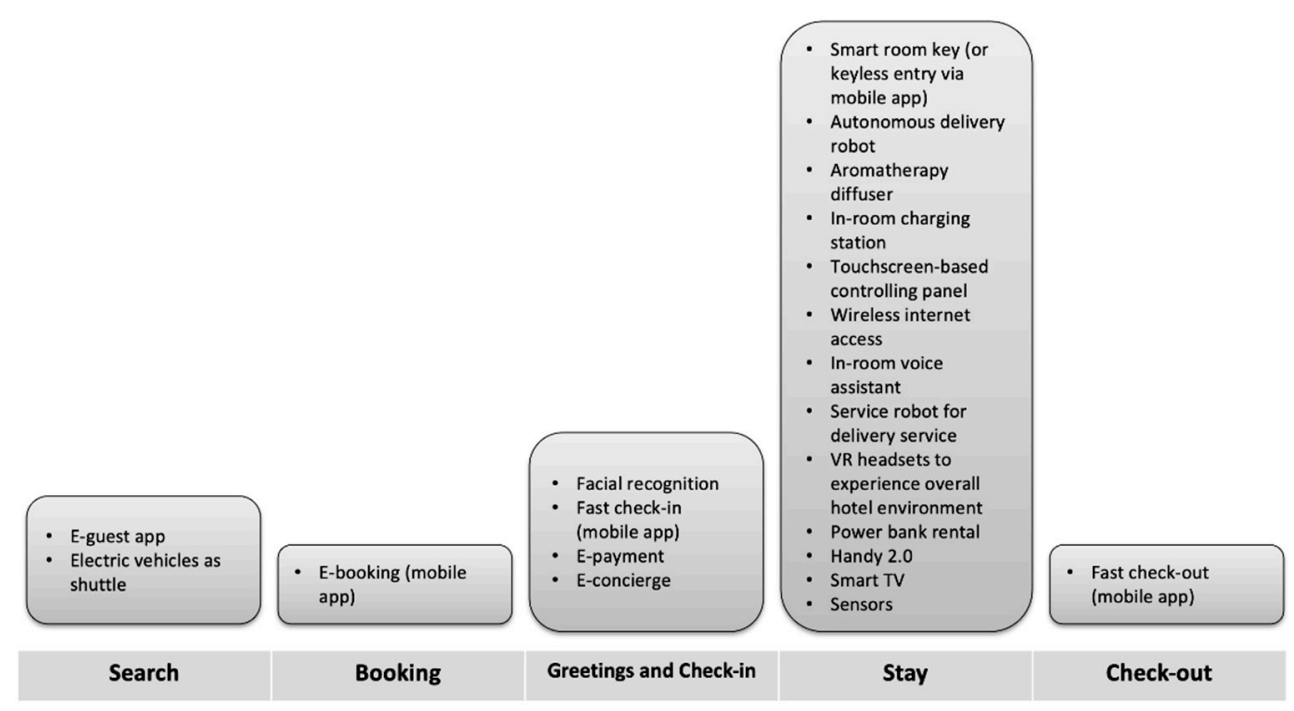

Figure 2. Smart technologies over the five guest service touchpoints; Source: Authors' own figure developed based on the interview results.

\subsection{Survey}

Based on the above interview findings, a questionnaire was designed for use in a survey. After running a pilot survey with 20 respondents, the questionnaire, comprising three parts, was finalised. Part 1 provided an introduction of the purpose of the study and the scope and definitions of the smart technologies in the context of this study. Part 2 sought to identify demographic attributes of the respondents, including gender, education level, age and place of origin. Part 3 contained twenty-eight questions that measure the nine constructs (PU, PEU, PS, COM, SN, SEL, PBC, ATU and ITU) shown in Appendix A (Table A1). The judgement questions for this part adopt a seven-point scale, from 1 (strongly disagree) to 7 (strongly agree).

For this survey, the survey administrators were sent to 11 popular tourist spots in Hong Kong: Avenue of Stars, Hong Kong Museum of History, Hong Kong Museum of Art, the Peak, Lan Kwai Fong, Man Mo Temple, Tai Kwun, Star Ferry Terminal, Hong Kong Park, Golden Bauhinia Square and Times Square. These places were selected based on two grounds: first, they are among the recommended attractions of the Hong Kong Tourism Board [77]; second, they are located in three areas (Central and Western district, Wai Chai district and Yau Tsim Mong district) with high levels of hotel density [78].

340 tourists who had hotel stay experience in Hong Kong were approached face-toface to participate in this survey. At the beginning of each survey interview, an introduction of smart technologies and examples of EE smart technologies commonly used in Hong Kong (e.g., e-guest apps for pre-arrival greeting, mobile apps for booking and self-check-in, facial recognition for self-check-in, e-payment for deposit payment, robotic concierge, touchscreen-based in-room controlling panel, service robot for delivery service, smart room key) were explained to the participant. This was to ensure that the participants had a consistent understanding of the EE smart technologies in the study.

Each of the survey interviews took around $20 \mathrm{~min}$ to complete. Among all the interviews, 28 interviewees did not answer all the questions in the questionnaire, resulting in a valid sample of 312. Table 2 shows the demographic information of the sample. 
Table 2. Demographic information of the sample.

\begin{tabular}{cccc}
\hline Information & Category & Number & Percentage \\
\hline \multirow{2}{*}{ Gender } & Male & 145 & $46 \%$ \\
& Female & 167 & $54 \%$ \\
\hline \multirow{3}{*}{ Education } & Primary & 22 & $7 \%$ \\
& Secondary & 37 & $12 \%$ \\
& Tertiary & 239 & $77 \%$ \\
& Others & 14 & $4 \%$ \\
\hline \multirow{3}{*}{ Age } & $18-30$ & 145 & $46 \%$ \\
& $31-40$ & 72 & $23 \%$ \\
& $41-50$ & 37 & $12 \%$ \\
& $51-60$ & 44 & $14 \%$ \\
\multirow{3}{*}{ Origin } & 61 and above & 14 & $4 \%$ \\
& Asia & 171 & $55 \%$ \\
& Europe & 72 & $23 \%$ \\
& North America & 48 & $15 \%$ \\
\hline Total & Oceania & 12 & $3 \%$ \\
\hline
\end{tabular}

Source: Authors' data based on the hotel experience-enhancement smart technologies survey results, Hong Kong, $2019(\mathrm{~N}=312)$.

\section{Analysis and Findings}

Using STATA 15.1, the data obtained from the survey interviews were analysed by structural equation modelling (SEM) to test the relationships and interactions among the variables, including their direct and indirect effects [79]. Commonly used in customer behaviour analysis, SEM models simultaneous interactions among exogenous and endogenous variables [80] and it allows for breaking down the total effect of a variable into direct and indirect effects through path analysis [81].

\subsection{Factors Loading and Cronbach's Alpha Reliability Test}

We tested the reliability of the indicators through explanatory factor analysis and Cronbach's Alpha test. Table 3 presents the test results. All the factor loading values of the constructs are above 0.5 , which satisfies the cut-off point [82]. All values of the Cronbach alpha test are above 0.8 , showing high-level internal consistency. This shows that the conceptual construct has reasonable degree of reliability and internal consistency.

Table 3. Factors loading and Cronbach's alpha of the measurement items and constructs.

\begin{tabular}{cccc}
\hline Constructs & Items & Factor Loading & Cronbach Alpha $(\alpha)$ \\
\hline 1. Intention to use (ITU) & ITU1 & 0.89 & 0.92 \\
2. Perceived usefulness (PU) & ITU2 & 0.89 & 0.93 \\
& PU1 & 0.85 & 0.89 \\
PU2 & PU3 & 0.82 & 0.93 \\
3. Perceived ease of use (PEU) & PU4 & 0.92 & 0.83 \\
& PEU1 & 0.83 & 0.92 \\
& PEU2 & 0.89 & 0.94 \\
\hline
\end{tabular}


Table 3. Cont.

\begin{tabular}{cccc}
\hline Constructs & Items & Factor Loading & Cronbach Alpha $(\alpha)$ \\
\hline \multirow{3}{*}{ 6. Perceived behavioural control (PBC) } & PBC1 & 0.67 & \\
& PBC2 & 0.84 & 0.83 \\
& PBC3 & 0.77 & \\
& COM1 & 0.84 & \multirow{2}{*}{0.91} \\
7. Compatibility (COM) & COM2 & 0.84 & \\
& COM3 & 0.82 & \multirow{2}{*}{0.92} \\
& COM4 & 0.86 & \multirow{2}{*}{0.90} \\
\hline \multirow{2}{*}{ 8. Self-efficacy (SEL) } & COM5 & 0.78 & 0.88 \\
& SEL1 & 0.88 & \\
\hline \multirow{2}{*}{ 9. Perceived security (PS) } & SEL2 & 0.86 & \\
& PS1 & 0.86 &
\end{tabular}

Source: Authors' data based on the hotel experience-enhancement smart technologies survey results, Hong Kong, $2019(\mathrm{~N}=312)$.

\subsection{Correlation Analysis}

We performed correlation analysis to evaluate the linear relationships of pair-wise constructs in each path of technology acceptance. Table 4, which summarises the zero-order correlation coefficients of the paired constructs, shows that ITU, PU, PEU, SN, ATU, COM, SEL and PS are significantly correlated with their pair-wise indicators. PBC significantly correlates with ATU but is insignificantly correlated with the other variables. Meanwhile, the correlation coefficients of some indicators are quite high, such as ITU with ATU, COM with ITU and SEL with PEU. For example, the correlation coefficient of ITU and ATU is 0.77 , indicating that the relationship between these two indicators is strong and positive. At the same time, the standard deviation values of these variables are not high, indicating that the response has been fairly concentrated to the mean.

Table 4. Mean, standard deviation, and correlation analysis results.

\begin{tabular}{|c|c|c|c|c|c|c|c|c|c|c|}
\hline & Mean & SD & 1 & 2 & 3 & 4 & 5 & 6 & 7 & 8 \\
\hline 1. ITU & 11.09 & 2.16 & & & & & & & & \\
\hline 2. PU & 21.90 & 4.25 & $0.58^{* * *}$ & & & & & & & \\
\hline 3. PEU & 20.89 & 4.55 & $0.61^{* * *}$ & $0.43^{* * *}$ & & & & & & \\
\hline 4. SN & 14.08 & 3.51 & $0.49 * * *$ & $0.42 * * *$ & $0.43^{* * *}$ & & & & & \\
\hline 5. ATU & 15.86 & 3.34 & $0.77^{* * *}$ & $0.64^{* * *}$ & $0.59 * * *$ & $0.58^{* * *}$ & & & & \\
\hline 6. $\mathrm{PBC}$ & 16.49 & 3.08 & $-0.09^{\mathrm{ns}}$ & $0.001^{\mathrm{ns}}$ & $-0.08^{\mathrm{ns}}$ & $0.06^{\mathrm{ns}}$ & $-0.11^{* *}$ & & & \\
\hline 7.COM & 27.52 & 5.20 & $0.71^{* * *}$ & $0.51 * * *$ & $0.67 * * *$ & $0.42^{* * *}$ & $0.67^{* * *}$ & $-0.14 *$ & & \\
\hline 8. SEL & 10.06 & 2.43 & $0.67 * * *$ & $0.50 * * *$ & $0.71 * * *$ & $0.48^{* * *}$ & $0.71^{* * *}$ & $-0.08^{\mathrm{ns}}$ & $0.68^{* * *}$ & \\
\hline 9. PS & 9.650 & 2.28 & $0.35^{* * *}$ & $0.34 * * *$ & $0.36^{* * *}$ & $0.32^{* * *}$ & $0.40^{* * *}$ & $-0.20 * * *$ & 0.39 *** & $0.45^{* * *}$ \\
\hline
\end{tabular}

Note: * Correlation * significant at $p<0.05,{ }^{* *}$ significant at $p<0.01,{ }^{* * *}$ significant at $p<0.001$; ${ }^{\text {ns }}$ Correlation is not significant $(p$-value $>0.05)$; Source: Authors' data based on the hotel experience-enhancement smart technologies survey results, Hong Kong, 2019 ( N = 312).

\subsection{Model Fitness}

We applied SEM to establish the model of technology acceptance behaviour [83]. Summarised in Table 5 are the results of Chi-square $\left(\chi^{2}\right)$ and five other indices: RMSEA, AIC, BIC, CFI and TLI. The $\chi^{2}$ value assesses the magnitude of discrepancy between the sample and fitted co-variances matrices (Hu and Bentler, 1992). Compared to the threshold value ( $p=0.05$ ), the computed $p$ value is far smaller and thus indicates a significant result leading to a good model fit. As for RMSEA (0.08: good fit; 0.08 to 0.10: mediocre fit) [84], the calculated RMSEA - being 0.08-indicates a fair fit as the RMSEA cut-off points have been reduced considerably in the last two decades [80]. Given a moderate sample size (312), we also examined the CFI value for making comparison between the sample covariance matrix and its null model. The computed CFI is 0.918 , which is close to 1.0, indicating a good fit for the model. With TLI $>0.9$ being the recommended threshold, the computed value (0.909) also indicates a good fit for the model. Overall, the test supports a good fit between the data and the proposed structural model. 
Table 5. Overall model fit indices of the proposed model.

\begin{tabular}{ccc}
\hline Statistics & Recommended & Computed \\
\hline$\chi^{2}$ & - & 1015.539 \\
Degree of freedom & - & 339 \\
Root mean square error of approximation (RMSEA) & $<0.10$ & 0.08 \\
Up bound of 90\% CI of RMSEA & $<0.10$ & 0.086 \\
Akaike's information criterion (AIC) & - & $20,519.912$ \\
Bayesian information criterion (BIC) & $>0.90$ & $20,875.497$ \\
Comparative fit index (CFI) & $>0.90$ & 0.918 \\
Tucker-Lewis index (TLI) & 0.909 \\
\hline
\end{tabular}

Source: Authors' data based on the hotel experience-enhancement smart technologies survey results, Hong Kong, $2019(\mathrm{~N}=312)$.

\subsection{Hypothesis Testing}

Table 6 summarises the hypotheses test results, which were obtained through estimating the path coefficients to test the relationships between the dependent and independent variables. All the proposed structural variable coefficients are standardized, and statistically significant $(p<0.001)$, suggesting that all the covariates have a positive effect on intention to use. The structural variable coefficients reflect the direct, indirect and total effects of hotel technology acceptance.

Table 6. Path analysis for hypothesis testing.

\begin{tabular}{|c|c|c|c|c|c|c|}
\hline Hypothesis & & Effects & & Structural Coefficient & Standard Error & Remarks \\
\hline $\mathrm{H} 1$ & ATU & $\rightarrow$ & ITU & $0.877^{* * *}$ & 0.018 & Support \\
\hline $\mathrm{H} 2$ & PU & $\rightarrow$ & ATU & $0.718^{* * *}$ & 0.031 & Support \\
\hline H3 & PEU & $\rightarrow$ & ATU & $0.703^{* * *}$ & 0.033 & Support \\
\hline $\mathrm{H} 4$ & PBC & $\rightarrow$ & ITU & $0.724^{* * *}$ & 0.035 & Support \\
\hline $\mathrm{H} 5$ & $\mathrm{SN}$ & $\rightarrow$ & ITU & $0.294^{* * *}$ & 0.084 & Support \\
\hline H6 & PS & $\rightarrow$ & ATU & $0.463^{* * *}$ & 0.049 & Support \\
\hline $\mathrm{H} 7$ & $\mathrm{COM}$ & $\rightarrow$ & ATU & $0.789^{* * *}$ & 0.027 & Support \\
\hline H8 & $\mathrm{SN}$ & $\rightarrow$ & PU & $0.180 * * *$ & 0.068 & Support \\
\hline H9 & $\mathrm{SN}$ & $\rightarrow$ & PEU & $0.191 * * *$ & 0.070 & Support \\
\hline H11 & SEL & $\rightarrow$ & PU & $0.266^{* * *}$ & 0.047 & Support \\
\hline \multirow[t]{10}{*}{$\mathrm{H} 12$} & SEL & $\rightarrow$ & PEU & $0.643^{* * *}$ & 0.041 & Support \\
\hline & & & & Direct Effects & Indirect Effects & Total Effect on ITU \\
\hline & \multicolumn{2}{|c|}{$\mathrm{SN}$} & & $0.325(0.95) * * *$ & $0.256(0.068) * * *$ & $0.581(0.061) * * *$ \\
\hline & \multicolumn{2}{|c|}{ SEL } & & - & $0.649(0.054) * * *$ & $0.649(0.054) * * *$ \\
\hline & \multicolumn{2}{|c|}{ PU } & & - & $0.599(0.049) * * *$ & $0.599(0.048) * * *$ \\
\hline & \multicolumn{2}{|c|}{ PEU } & & - & $0.617(0.052) * * *$ & $0.617(0.052) * * *$ \\
\hline & \multicolumn{2}{|c|}{ PS } & & - & $0.412(0.056) * * *$ & $0.412(0.056)^{* * *}$ \\
\hline & \multicolumn{2}{|c|}{$\mathrm{COM}$} & & - & $0.660(0.054) * * *$ & $0.660(0.054)^{* * *}$ \\
\hline & \multicolumn{2}{|c|}{ PBC } & & $0.569(0.054)^{* * *}$ & - & $0.569(0.054) * * *$ \\
\hline & \multicolumn{2}{|c|}{ ATU } & & $0.878(0.045) * * *$ & - & $0.878(0.045) * * *$ \\
\hline
\end{tabular}

Note: ${ }^{* * *}$ significant at $p<0.001$; number in parentheses are standard errors; Source: Authors' data based on the hotel experienceenhancement smart technologies survey results, Hong Kong, 2019 (N = 312).

All the paths specified in the TAM model are significant with direct and indirect effects of PU, PEU and ATU. As the model predicts, ATU ( $\beta=0.877, p<0.001)$, PBC $(\beta=0.724$, $p<0.001)$ and SN $(\beta=0.294, p<0.001)$ have a significant influence on ITU. Hypothesis tests $\mathrm{H} 1, \mathrm{H} 4$ and $\mathrm{H} 5$ support the traditional TAM propositions on user attitude-intention relations and the TPB-TAM connection. $\mathrm{PU}(\beta=0.718, p<0.001)$, $\mathrm{PEU}(\beta=0.703, p<0.001)$, PS $(\beta=0.463, p<0.001)$ and COM $(\beta=0.789, p<0.001)$ are significant predictors of ATU. Hypothesis tests $\mathrm{H} 2, \mathrm{H} 3, \mathrm{H} 6$ and $\mathrm{H} 7$ support their motivational effects on user's attitude. Subjective norms (H8: $\beta=0.180, p<0.001 ; \mathrm{H} 9: \beta=0.191, p<0.001$ ) have significant influences on PU and PEU, albeit to a lesser extent. Customer's self-efficacy (SEL) has significant influences on PU and PEU (H11: $\beta=0.266, p<0.001 ; \mathrm{H} 12: \beta=0.643, p<0.001$ ). Finally, analysis of the direct and indirect effects of different variables show that $\mathrm{SN}$ has both direct and indirect effects on ITU, and the direct effect is stronger than the indirect 
effect. PBC and ATU have direct effects on the ITU, while other constructs have indirect effects on ITU.

Figure 3 visually presents the full SEM results, and solid lines in the diagram denote statistically significant coefficients. The diagram indicates that ITU is directly associated with three variables: SN, PBC and ATU. Meanwhile, SEL, PU, PEU, PS and COM are indirectly associated with ITU.

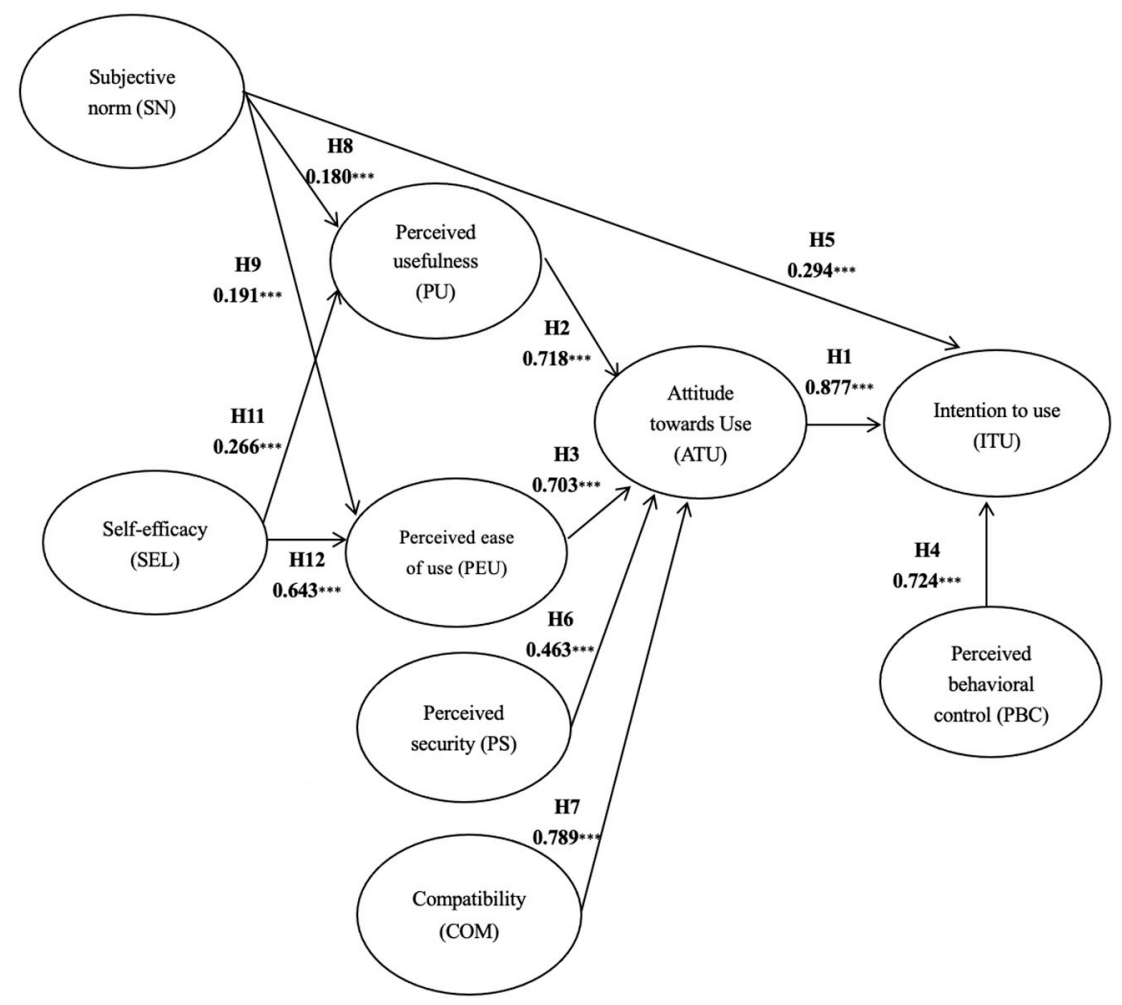

Figure 3. Results of tourists' acceptance of smart technology; Source: Authors' data based on the hotel experience-enhancement smart technologies survey results, Hong Kong, 2019 ( $N=312)$. Note: *** significant at $p<0.001$.

\section{Implications}

\subsection{Theoretical Implications}

In this study, the definition and scope of hotel smart technologies are reinforced. This study highlights the business and service nature of smart technologies in the hotel sector and frames this group of technologies as EE smart technologies. In fact, the development of EE smart technologies was initiated by hotel owners and operators to improve service quality as well as to facilitate sales and marketing based on behavioural data of their customers. Such technologies were not developed for isolated functions, but were designed with an intention to integrate with each other as a package of service delivery. For example, "smart hotel room" is a system supported by the integration of various types of smart technologies used in the hotel room area. These technologies were designed to streamline the service delivery process from initial contact to post-consumption marketing. The future trend of EE technologies lies in their seamless integration to provide smooth service experience to tourists. Thus, it is necessary to understand the EE smart technologies instead of investigating only some of the smart technologies. Furthermore, this study leads to several theoretical contributions. First, the findings of this study confirm that a TAM-based conceptual framework provides an extensive comprehension of tourists' behaviour and intention of using smart technologies. Although TAM is widely used to study employees' and hotel guests' acceptance of specific types of technology in the hotel sector [29-35,38], the role of PS and COM in influencing tourists' attitude towards using hotel smart technologies 
were ignored in the literature. This study confirms that PS and COM as tourists' individuallevel factors have influences on their acceptance of hotel smart technologies. As self-service technologies are commonly adopted in the hospitality setting [32,85], more emphases shall be placed on investigating the role of tourists' individual-level factors in affecting smart technologies acceptance [34]. This study also tested how SN and SEL affect the TAM model. The four hypotheses were supported, implying that some human motives of technology acceptance affect the TAM model [61]. Second, TAM provides a fundamental basis for consumer behavioural studies related to new technology acceptance, and its explaining power can be further strengthened when it incorporates additional variables to adapt to the contexts of new consumption styles and new technology applications. As using hotel smart technology can be seen as a consumption process that includes learning, self-reflecting and benchmarking behavioural activities, variables from TPB, PS, COM and SEL, which were proposed with reference to the actual situation of the hotel service receiving context, have been incorporated into the TAM-based conceptual framework [61]. Third, both TAM and TPB have manifested a high level of adaptability when they are used in combination with other theoretical constructs to explain complicated customer behaviour. Although the issue of TAM oversaturation is often criticised, the statistical findings of this study reveal that the extended TAM model is powerful in predicting the behaviour of intention to use. Last, the TAM-based conceptual framework is foreseen to be adjustable for use in future studies to investigate acceptance of smart technologies in contexts beyond the hotel and tourism environment.

\subsection{Practical Implications}

This study also results in important implications to smart technologies application in the hotel sector. First, PS and COM were found to have positive influences on attitude as antecedents of tourists' intention to use smart technologies. This implies that extra effort should be committed to guaranteeing tourists' data privacy, and this should be emphasised when hotels promote smart technologies that involve the inputting of personal information. Second, as smart technologies are usually used to enhance hotel brands and strengthen their positions of being innovative, over-emphasising the use of smart technologies may create a cognitive barrier to people who perceive themselves to be slow to adapt new technologies. Therefore, it is necessary to downplay the "innovative" aspect when applying smart technologies to services delivery. Third, this study provides empirical evidence for hotel practitioners to review hotels' adoption of smart technologies in enhancing guests' experience, especially when they need to make decisions on the application of smart technologies under resource-constrained circumstances. The use of smart technologies has become a prevailing trend in service industries, including the hotel industry. With the continued advancement of the technologies, the functions of hotel smart technologies will be further improved. Although users' behaviour will change over time, a clear understanding of the current hotel guest behavioural intention and the factors affecting the intention will facilitate the hotel sector to implement adjustments in management decision-making and marketing strategy formation.

\section{Conclusions}

Previous studies on hotel smart technology acceptance usually focus on a particular technology, such as reservation websites, self-service kiosks, etc. While they have provided useful information about the applications of these technologies to hospitality services delivery, tourists' acceptance of hotel smart technologies as a whole remains underexplored. Contributing knowledge to this niche area, this study has identified the commonly used EE smart technologies in hotels, distinguished experience-enhancement (EE) smart technologies from operating smart technologies, and established a TAM-based conceptual framework with enhanced explaining power to investigate tourists' behavioural intention of using smart technologies. 
Based on the TAM-based conceptual framework and using the SEM technique, the study has successfully modelled the tourists' acceptance of smart technologies. The findings from the statistical analysis, which have revealed the interrelationships between the various model parameters, contribute to the understanding of the effects of those parameters on the tourists' acceptance of smart technologies.

This study has several limitations. First, the study was conducted in Hong Kong and thus some findings of this study are specific the city's context. Second, though the sample size is sufficient for statistical analysis, it may still be too limited for generalization. Future studies can be extended into other contexts with larger sample size to increase the validity and applicability of their findings. Further, the present study combines the TAM with TPB to develop its theoretical model. Future studies can combine TAM with other theories and models, such as innovative diffusion theory, for enhanced results and implications.

Author Contributions: Conceptualisation: D.H., H.H., H.W. and J.H.K.L.; Methodology: D.H. and H.H.; Data curation: H.H.; Formal Analysis: D.H., H.H., H.W. and J.H.K.L.; Original draft preparation: H.H.; Writing-review and editing: H.W. and J.H.K.L. All authors have read and agreed to the published version of the manuscript.

Funding: This research received no external funding.

Institutional Review Board Statement: Not applicable.

Informed Consent Statement: Informed consent was obtained from all subjects involved in this study.

Data Availability Statement: Not applicable.

Acknowledgments: The authors would like to acknowledge Yi Xiao, a student at the School of Hotel and Tourism Management, CUHK, for her excellent research assistance and data collection administration. The authors would like to thank the anonymous reviewers for their constructive comments.

Conflicts of Interest: The authors declare no conflict of interest.

\section{Appendix A}

Table A1. Survey Variables and Measurement Instruments.

\begin{tabular}{|c|c|c|}
\hline Constructs & Items & Statements \\
\hline $\begin{array}{l}\text { 1. Intention to use } \\
\text { smart technology }\end{array}$ & $\begin{array}{l}\text { ITU1 } \\
\text { ITU2 }\end{array}$ & $\begin{array}{l}\text { Assuming that smart technology is available in hotels, I intend to use it. } \\
\text { Given that I have access to smart technology, I predict I would use it. }\end{array}$ \\
\hline 2.Perceived usefulness & $\begin{array}{l}\text { PU1 } \\
\text { PU2 } \\
\text { PU3 } \\
\text { PU4 }\end{array}$ & $\begin{array}{l}\text { Using smart technology provides convenience for my stay in the hotel. } \\
\text { Using smart technology enhances my experience in the hotel. } \\
\text { Using smart technology enhances the effectiveness of hotel service delivery } \\
\text { I find smart technology to be useful for my stay in the hotel. }\end{array}$ \\
\hline 3. Perceived ease of use & $\begin{array}{l}\text { PEU1 } \\
\text { PEU2 } \\
\text { PEU3 } \\
\text { PEU4 }\end{array}$ & $\begin{array}{l}\text { Smart technology seems easy and clear for me to understand. } \\
\text { Using smart technology does not require a lot of effort. } \\
\text { I find smart technology to be easy to use. } \\
\text { I find it easy to have smart technology to help me to use hotel service. }\end{array}$ \\
\hline 4. Subjective Norm & SN2 & $\begin{array}{l}\text { Most people who are important to me think I should use smart technology to receive } \\
\text { service from hotels. } \\
\text { Most people who are important to me want me to use smart technology to receive } \\
\text { service from hotels. } \\
\text { People whose opinion I value would prefer that I use smart technology to receive service } \\
\text { from hotels. }\end{array}$ \\
\hline $\begin{array}{l}\text { 5. Attitude towards using smart } \\
\text { technology }\end{array}$ & $\begin{array}{l}\text { ATU1 } \\
\text { ATU2 } \\
\text { ATU3 }\end{array}$ & $\begin{array}{l}\text { I think it would be very good to use smart technology to receive service from hotels. } \\
\text { In my opinion it would be very desirable to use smart technology to receive service } \\
\text { from hotels. } \\
\text { It would be much better for me to use smart technology to receive service from hotels. }\end{array}$ \\
\hline 6.Perceived behaviour control & $\begin{array}{l}\text { PBC1 } \\
\text { PBC2 } \\
\text { PBC3 }\end{array}$ & $\begin{array}{l}\text { Whether or not I use smart technology to receive service from hotels when traveling is } \\
\text { completely up to me. } \\
\text { I am confident that if I want, I can receive service by using smart technology. } \\
\text { I have resources, time and opportunities to use smart technology to receive hotel service } \\
\text { when traveling. }\end{array}$ \\
\hline
\end{tabular}


Table A1. Cont.

\begin{tabular}{|c|c|c|}
\hline Constructs & Items & Statements \\
\hline \multirow{5}{*}{ 7. Compatibility } & COM1 & I like to try new technology. \\
\hline & COM2 & I like to adopt new innovation. \\
\hline & COM3 & Smart technology fits well the way I access and receive service from hotels. \\
\hline & COM4 & Using smart technology to receive service from hotels is compatible with the way I travel. \\
\hline & COM5 & $\begin{array}{l}\text { Using smart technology to receive service from hotels. } \\
\text { fit my lifestyle. }\end{array}$ \\
\hline \multirow{2}{*}{ 8. Self-efficacy } & SEL1 & I am proficient in using smart technology to receive service from hotels. \\
\hline & SEL2 & I feel confident that I can use smart technology to receive service from hotels. \\
\hline \multirow{2}{*}{ 9. Perceived security } & PS1 & Using smart technology to receive service from hotels is safe. \\
\hline & PS2 & In general, using smart technology to receive service from hotel is secured. \\
\hline
\end{tabular}

\section{References}

1. Singapore Tourism Board. Smart Hotel Technology Guide 2019. Available online: https:/ /www.stb.gov.sg/content/dam/stb / documents/industries/hotel/Smart\%20Hotel\%20Technology\%20Guide\%202019.pdf (accessed on 28 October 2020).

2. Buhalis, D.; Leung, R. Smart hospitality-Interconnectivity and interoperability towards an ecosystem. Int. J. Hosp. Manag. 2018, 71, 41-50. [CrossRef]

3. Lee, P.; Hunter, W.C.; Chung, N. Smart Tourism City: Developments and Transformations. Sustainability 2020, 12, 3958. [CrossRef]

4. Morosan, C.; Jeong, M. Users' perceptions of two types of hotel reservation Web sites. Int. J. Hosp. Manag. 2008, 27, 284-292. [CrossRef]

5. Kim, J.; Christodoulidou, N.; Brewer, P. Impact of Individual Differences and Consumers' Readiness on Likelihood of Using Self-Service Technologies at Hospitality Settings. J. Hosp. Tour. Res. 2010, 36, 85-114. [CrossRef]

6. Kim, M.; Qu, H. Travelers' behavioral intention toward hotel self-service kiosks usage. Int. J. Contemp. Hosp. Manag. 2014, 26, 225-245. [CrossRef]

7. Lim, W.M.; Teh, P.-L.; Ahmed, P.K.; Cheong, S.-N.; Ling, H.-C.; Yap, W.-J. Going keyless for a seamless experience: Insights from a unified hotel access control system. Int. J. Hosp. Manag. 2018, 75, 105-115. [CrossRef]

8. Bibri, S.E.; Krogstie, J. Smart sustainable cities of the future: An extensive interdisciplinary literature review. Sustain. Cities Soc. 2017, 31, 183-212. [CrossRef]

9. Foroudi, P.; Gupta, S.; Sivarajah, U.; Broderick, A. Investigating the effects of smart technology on customer dynamics and customer experience. Comput. Hum. Behav. 2018, 80, 271-282. [CrossRef]

10. Pizam, A. The internet of things (IoT): The next challenge to the hospitality industry. Int. J. Hosp. Manag. 2017, 62, 132-133. [CrossRef]

11. Worden, K.; Bullough, W.; Haywood, J. The Smart Approach-An Introduction to Smart Technologies; Smart Technologies; River Edge; World Scientific: Singapore, 2003.

12. Leonidis, A.; Korozi, M.; Margetis, G.; Grammenos, D.; Stephanidis, C. An intelligent hotel room. In Proceedings of the International Joint Conference on Ambient Intelligence, Dublin, Ireland, 3-5 December 2013; Springer: Cham, Switzerland, 2013; pp. 241-246.

13. Zoughbi, S.; Al-Nasrawi, S. Regional development getting smarter with ICT. In Encyclopedia of Information Science and Technology, 3rd ed.; IGI Global: Hershey, PA, USA, 2015; pp. 6525-6533.

14. Li, Y.; Hu, C.; Huang, C.; Duan, L. The concept of smart tourism in the context of tourism information services. Tour. Manag. 2017, 58, 293-300. [CrossRef]

15. Su, K.; Li, J.; Fu, H. Smart city and the applications. In Proceedings of the 2011 International Conference on Electronics, Communications and Control (ICECC), Ningbo, China, 9-11 September 2011; pp. 1028-1031.

16. Nizic, M.; Karanovic, G.; Ivanovic, S. Importance of intelligent rooms for energy savings in the hotel industry. Tour. Hosp. Manag. 2008, 14, 323-336.

17. Yu, M.; Lee, B. Efficiency and effectiveness of service business: Evidence from international tourist hotels in Taiwan. Tour. Manag. 2009, 30, 571-580. [CrossRef]

18. Kim, J.; Connolly, D.J.; Blum, S. Mobile Technology: An Exploratory Study of Hotel Managers. Int. J. Hosp. Tour. Adm. 2014, 15, 417-446. [CrossRef]

19. Jeremen, D.E.; Jędrasiak, M.; Rapacz, A. The Concept of Smart Hotels as an Innovation on the Hospitality Industry Market-Case Study of Puro Hotel in Wrocław. Èkon. Probl. Tur. 2016, 36, 65-75. [CrossRef]

20. Okumus, B.; Ali, F.; Bilgihan, A.; Ozturk, A.B. Psychological factors influencing customers' acceptance of smartphone diet apps when ordering food at restaurants. Int. J. Hosp. Manag. 2018, 72, 67-77. [CrossRef]

21. Xiang, Z.; Schwartz, Z.; Gerdes, J.H., Jr.; Uysal, M. What can big data and text analytics tell us about hotel guest experience and satisfaction? Int. J. Hosp. Manag. 2015, 44, 120-130. [CrossRef]

22. Zhao, Y.; Xu, X.; Wang, M. Predicting overall customer satisfaction: Big data evidence from hotel online textual reviews. Int. J. Hosp. Manag. 2019, 76, 111-121. [CrossRef] 
23. Pai, C.K.; Liu, Y.; Kang, S.; Dai, A. The Role of Perceived Smart Tourism Technology Experience for Tourist Satisfaction, Happiness and Revisit Intention. Sustainability 2020, 12, 6592. [CrossRef]

24. Chan, E.S.W.; Okumus, F.; Chan, W. The Applications of Environmental Technologies in Hotels. J. Hosp. Mark. Manag. 2017, 26, 23-47. [CrossRef]

25. Hou, H.; Wu, H. Tourists' Knowledge of Green Building Design and Their Intention of Staying in Green Hotels. Tour. Hosp. Res. 2020, 21, 115-128. [CrossRef]

26. Okumus, F. Facilitating knowledge management through information technology in hospitality organizations. J. Hosp. Tour. Technol. 2013, 4, 64-80. [CrossRef]

27. Cantallops, A.S.; Salvi, F. New consumer behaviour: A review of research on eWOM and hotels. Int. J. Hosp. Manag. 2014, 30, 41-51. [CrossRef]

28. Wang, D.; Xiang, Z.; Law, R.; Ki, T.P. Assessing Hotel-Related Smartphone Apps Using Online Reviews. J. Hosp. Mark. Manag. 2015, 25, 291-313. [CrossRef]

29. Leung, R. Smart hospitality: Taiwan hotel stakeholder perspectives. Tour. Rev. 2019, 74, 50-62. [CrossRef]

30. Kuo, C.-M.; Chen, L.-C.; Tseng, C.-Y. Investigating an innovative service with hospitality robots. Int. J. Contemp. Hosp. Manag. 2017, 29, 1305-1321. [CrossRef]

31. Lam, T.; Cho, V.; Qu, H. A study of hotel employee behavioural intentions towards adoption of information technology. Hosp. Manag. 2007, 26, 49-65. [CrossRef]

32. Lema, J.D. Preparing Hospitality Organizations for Self-Service Technology. J. Hum. Resour. Hosp. Tour. 2009, 8, 153-169. [CrossRef]

33. Sun, S.; Lee, P.C.; Law, R.; Hyun, S.S. An investigation of the moderating effects of current job position level and hotel work experience between technology readiness and technology acceptance. Int. J. Hosp. Manag. 2020, 90, 102633. [CrossRef]

34. Sun, S.; Lee, P.C.; Law, R.; Zhong, L. The impact of cultural values on the acceptance of hotel technology adoption from the perspective of hotel employees. J. Hosp. Tour. Manag. 2020, 44, 61-69. [CrossRef]

35. Murphy, H.C.; Rottet, D. An exploration of the key hotel processes implicated in biometric adoption. Int. J. Contemp. Hosp. Manag. 2009, 21, 201-212. [CrossRef]

36. Sarmah, B.; Kamboj, S.; Rahman, Z. Co-creation in hotel service innovation using smart phone apps: An empirical study. Int. J. Contemp. Hosp. Manag. 2017, 29, 2647-2667. [CrossRef]

37. Wu, H.C.; Cheng, C.C. Relationships between technology attachment, experiential relationship quality, experiential risk and experiential sharing intentions in a smart hotel. J. Hosp. Tour. Manag. 2018, 37, 42-58. [CrossRef]

38. Shin, H.; Perdue, R.R. Self-Service Technology Research: A bibliometric co-citation visualization analysis. Int. J. Hosp. Manag. 2019, 80, 101-112. [CrossRef]

39. Frank, J.; Harnisch, M.J. Review on benefits and risks of personalization and solutions for privacy concerns. Comput. Commun. Collab. 2014, 2, 35-46.

40. Buhalis, D.; Amaranggana, A. Smart Tourism Destinations Enhancing Tourism Experience through Personalisation of Services; ENTER 2015 Proceedings; Tussyadiah, I., Inversini, A., Eds.; Springer: New York, NY, USA, 2015; pp. 377-390.

41. Gupta, S.; Vajic, M. The Contextual and Dialectical Nature of Experiences; SAGE Publications, Inc.: Thousand Oaks, CA, USA, 2012; pp. 33-51.

42. Lai, I.K.W. Traveler Acceptance of an App-Based Mobile Tour Guide. J. Hosp. Tour. Res. 2015, 39, 401-432. [CrossRef]

43. Ozturk, A.B.; Hancer, M. The Effects of Demographics and Past Experience on RFID Technology Acceptance in the Hospitality Industry. Int. J. Hosp. Tour. Adm. 2015, 16, 275-289. [CrossRef]

44. Lopez-Bonilla, J.M.; Lopez-Bonilla, L.M. Self-service technology versus traditional service: Examining cognitive factors in the purchase of the airline ticket. J. Travel Tour. Mark. 2013, 30, 497-508. [CrossRef]

45. López-Bonilla, J.M.; López-Bonilla, L.M. Self-consciousness profiles in the acceptance of airline e-ticketing services. Anatolia 2015, 26, 447-458. [CrossRef]

46. Kim, J.; Okumus, F.; Okumus, F. An extended technology acceptance model in behavioral intention toward hotel tablet apps with moderating effects of gender and age. Int. J. Contemp. Hosp. Manag. 2016, 28, 1535-1553. [CrossRef]

47. Dieck, M.C.T.; Jung, T.H.; Kim, W.G.; Moon, Y. Hotel guests' social media acceptance in luxury hotels. Int. J. Contemp. Hosp. Manag. 2017, 29, 530-550. [CrossRef]

48. Davis, F.D.; Bagozzi, R.P.; Warshaw, P.R. User acceptance of computer technology: A comparison of two theoretical models. Manag. Sci. 1989, 35, 982-1003. [CrossRef]

49. Yousafzai, S.Y.; Foxall, G.R.; Pallister, J.G. Technology acceptance: A meta-analysis of the TAM: Part 1. J. Model. Manag. 2007, 2, 251-280. [CrossRef]

50. Yousafzai, S.Y.; Foxall, G.R.; Pallister, J.G. Technology acceptance: A meta-analysis of the TAM: Part 2. J. Model. Manag. 2007, 2, 281-304. [CrossRef]

51. Ajzen, I.; Fishbein, M. Understanding Attitudes and Predicting Social Behavior; Prentice-Hall: Englewood Cliffs, NJ, USA, 1980.

52. Davis, F. Perceived usefulness, perceived ease of use, and user acceptance of information technology. MIS Q. 1989, 13, 319-339. [CrossRef] 
53. Ignacio, J.; Alvin Malenab, R.; Pausta, C.; Beltran, A.; Belo, L.; Tanhueco, R.; Era, M.; Eusebio, R.; Promentilla, M.; Orbecido, A. Perceptions and Attitudes toward Eco-Toilet Systems in Rural Areas: A Case Study in the Philippines. Sustainability 2018, 10, 521. [CrossRef]

54. Legris, P.; Ingham, J.; Collerette, P. Why do people use information technology? A critical review of the technology acceptance model. Inf. Manag. 2003, 40, 191-204. [CrossRef]

55. Shih, H. Extended technology acceptance model of Internet utilization behaviour. Inf. Manag. 2004, 41, 719-729. [CrossRef]

56. Wixom, B.H.; Todd, P.A. A Theoretical Integration of User Satisfaction and Technology Acceptance. Inf. Syst. Res. 2005, 16, 85-102. [CrossRef]

57. Fishbein, M.; Ajzen, I. Belief, Attitude, Intention, and behaviour: An Introduction to Theory and Research; Addison-Wesley: Reading, MA, USA, 1975.

58. Ajzen, I. The theory of planned behaviour. Organ. Behav. Human. Decis. Process. 1991, 50, 179-211. [CrossRef]

59. Harwick, J.; Barki, H. Explaining the role of the user participation in information system use. Manag. Sci. 1994, 40, 440-465. [CrossRef]

60. Taylor, S.; Todd, P. Assessing IT Usage: The Role of Prior Experience. MIS Q. 1995, 19, 561-570. [CrossRef]

61. Moon, J.; Kim, Y. Extending the TAM model for the World Wide Web context. Inf. Manag. 2001, 38, 217-230. [CrossRef]

62. Mathieson, K.; Peacock, E.; Chin, W. Extending the technology acceptance model: The influence of perceived user resources. Database Adv. Inf. Syst. 2001, 32, 86-113. [CrossRef]

63. Chen, M.; Tung, P. Developing an extended theory of planned behaviour model to predict consumers' intention to visit green hotels. Int. J. Hosp. Manag. 2014, 36, 221-230. [CrossRef]

64. Mathieson, K. Predicting user intentions: Comparing the technology acceptance model with the theory of planned behaviour. Inf. Syst. Res. 1991, 2, 173-191. [CrossRef]

65. Pikkarainen, T.; Pikkarainen, K.; Karjaluoto, H.; Pahnila, S. Consumer acceptance of online banking: An extension of the technology acceptance model. Internet Res. 2004, 14, 224-235. [CrossRef]

66. Ha, S.; Stoel, L. Consumer e-shopping acceptance: Antecedents in a technology acceptance model. J. Bus. Res. 2009, 62, 565-571. [CrossRef]

67. Moore, G.C.; Benbasat, I. Development of an Instrument to Measure the Perceptions of Adopting an Information Technology Innovation. Inf. Syst. Res. 1991, 2, 192-222. [CrossRef]

68. Karahanna, E.; Agarwal, R.; Angst, C. Reconceptualizing compatibility beliefs in technology acceptance research. MIS Q. 2006, 30, 781-804. [CrossRef]

69. Rogers, E.M. The Diffusion of Innovation, 4th ed.; Free Press: New York, NY, USA, 1995.

70. Chau, P.Y.; Hu, P.J.H. Information technology acceptance by individual professionals: A model comparison approach. Decis. Sci. 2001, 32, 699-719. [CrossRef]

71. Chin, W.; Gopal, A. Adoption Intention in GSS: Relative Importance of Beliefs. ACM SIGMIS Database 1995, 26, 42-63. [CrossRef]

72. Hossain, L.; de Silva, A. Exploring user acceptance of technology using social networks. J. High Technol. Manag. Res. 2009, 20, 1-18. [CrossRef]

73. Yu, J.; Ha, I.; Choi, M.; Rho, J. Extending the TAM for a t-commerce. Inf. Manag. 2005, 42, 965-976. [CrossRef]

74. Venkatesh, V.; Davis, F. A theoretical extension of the technology acceptance model: Four longitudinal field studies. Manag. Sci. 2000, 46, 186-204. [CrossRef]

75. Vijayasarathy, L. Predicting consumer intentions to use on-line shopping: The case for an augmented technology acceptance model. Inf. Manag. 2004, 41, 747-762. [CrossRef]

76. Hong Kong Tourism Board PartnerNet. Company Directory. 2020. Available online: https://partnernet.hktb.com/en/e_ marketplace/company_directory/accommodation-hotels_resorts/index.html?isSearch=true\&gvHelperp=1 (accessed on 16 November 2020).

77. Hong Kong Tourism Board. Things to Do. 2020. Available online: www.discoverhongkong.com/eng/see-do/highlight-attractions/index.jsp (accessed on 25 September 2020).

78. Hong Kong Tourism Board PartnerNet. Hotel Supply Situation-As at December 2018. 2020. Available online: https://partnernet.hktb.com/en/research_statistics/index.html (accessed on 25 September 2020).

79. Sobel, M.E.; Van Der Heijden, P.G.M.; Van Gils, G.; Bouts, J.; Hox, J.J. Direct and Indirect Effects in Linear Structural Equation Models. Sociol. Methods Res. 1987, 16, 155-176. [CrossRef]

80. Hooper, D.; Coughlan, J.; Mullen, M. Structural equation modelling: Guidelines for determining model fit. Electron. J. Bus. Res. Methods 2008, 6, 53-60.

81. Hu, L.; Bentler, P. Cut-off criteria for fit indexes in covariance structure analysis: Conventional criteria versus new alternatives. Struct. Equ. Model. 1999, 6, 1-55. [CrossRef]

82. Hair, J.F.; Tatham, R.L.; Anderson, R.E.; Black, W. Multivariate Data Analysis, 7th ed.; Pearson Prentice Hall: Upper Saddle River, NJ, USA, 2010.

83. Kline, R. Principles and Practice of Structural Equation Modelling; Guilford Publications: New York, NY, USA, 2015. 
84. MacCallum, R.; Browne, M.; Sugawara, H. Power Analysis and Determination of Sample Size for Covariance Structure Modelling. Psychol. Methods 1996, 1, 130-149. [CrossRef]

85. Cuesta-Valiño, P.; Bolifa, F.; Núñez-Barriopedro, E. Sustainable, smart and Muslim-friendly tourist destinations. Sustainability 2020, 12, 1778. [CrossRef] 


\section{University Library}

\section{- M M I N E R VA A gateway to Melbourne's research publications}

Minerva Access is the Institutional Repository of The University of Melbourne

Author/s:

Han, D;Hou, HC;Wu, H;Lai, JHK

Title:

Modelling Tourists' Acceptance of Hotel Experience-Enhancement Smart Technologies

Date:

2021-04-16

Citation:

Han, D., Hou, H. C., Wu, H. \& Lai, J. H. K. (2021). Modelling Tourists' Acceptance of Hotel Experience-Enhancement Smart Technologies. Sustainability, 13 (8), https://doi.org/10.3390/ su13084462.

Persistent Link:

http://hdl.handle.net/11343/268237

License:

CC BY 